\section{Undergraduate students' perceptions on academic advising in Eritrean higher education: A case study of Eritrea Institute of Technology}

\author{
Frezghi, Tesfaldet $\bowtie$ \\ Eritrea Institute of Technology, Eritrea (selu.tesfie@gmail.com)
}

Received: 4 July 2018

Available Online: 14 February 2019

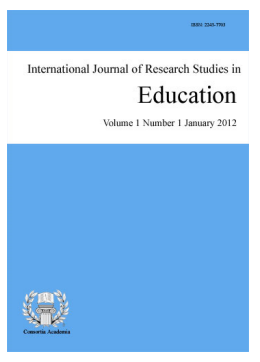

ISSN: 2243-7703 Online ISSN: 2243-7711

OPEN ACCESS

\begin{abstract}
Academic advising is an essential service in facilitating students' educational and personal goals at higher education institutions. It guides students with the institutional policies and procedures. It fosters students' interaction with academic advisors to exchange information about academic matters and future goals. This study examines undergraduate students' perspectives on academic advising at Eritrea Institute of Technology. The study also identifies some challenges concerning academic advising. Using semi-structured interview, the findings revealed that the experiences of undergraduate students on academic advising is characterized by infrequent advisee-advisor communication. However, it serves as bridge to other offices, offer information and motivate students for better outcomes. In addition, the study found that lack of close contacts, advisor's lack of follow-ups, and advisee shyness were some of the challenges identified related to academic advising. Despite its small scale, the study contributes in filling the research gap on academic advising in Eritrean higher education and enhancing the literature on the subject. In order to broaden our understanding on this area, further study is needed from the faculty members' perspectives and the voices from other Eritrean higher education institutions.
\end{abstract}

Keywords: academic advising; students' perceptions; higher education; Eritrea 


\section{Undergraduate students' perceptions on academic advising in Eritrean higher education: A case study of Eritrea Institute of Technology}

\section{Introduction}

Eritrea is a small country that is located in the North East of Africa. The drawback of long years of colonization followed by a protracted 1998-2000 border conflict with Ethiopia, affected the successful educational development in Eritrea. However, with these challenges and socio-economic impacts, the Government of the State of Eritrea has made an extensive investment to reform the education system in general, higher education in particular since the day of independence in 1991 (Rena, 2006). Investment on restructuring of higher education is among the main changes. Within higher education, academic advising is the basic aspect in predicting the success of students (O'Banion, 1994). The researcher is interested to study on academic advising of undergraduate students in Eritrean higher education institutions (HEIs) for three main reasons: expansion of higher education, my work experiences and lack of research in this case from Eritrea.

University of Asmara was the only university in Eritrea until 2003/2004. Nevertheless, in 2004/2005, seven new colleges established throughout the nation. These higher education institutions are administered under the auspices of National Board for Higher Education (NBHE) later named as National Commission for Higher Education (National Board for Higher Education [NBHE], 2010). The purpose of this reformation was to decentralize and increase students' access to higher education. With the expansion of HEIs, providing relevance, quality, and sustainable education in HEIs have been giving great emphasis (NBHE, 2014). This can be done through recruiting foreign lecturers or professors to fill the existed shortage of senior staff; improve teaching-learning resources; integrating information and communication technology and other supportive services to improve the quality of education and meet the diverse needs of students (NBHE, 2010). As part of the quality education, the NBHE in collaboration with all higher education institutions developed many guidelines to ensure the overall functions of institutions and their academic standards. The Faculty Evaluation and Promotion guideline is the one, which is established to facilitate the teaching and learning of the HEIs (NBHE, 2008). Among the functional statement of the guideline is academic advising. This guideline explains that academic advisors should offer orientation, ensure proper advising and meet students' needs.

The researcher worked for about a decade in the biggest HEI in Eritrea. As per the HEIs academic guideline, all teaching faculty members are expected to provide instruction and student advising as assigned by their respective departments. The guideline also stated that the teaching load includes holding class for the entire scheduled period, preparing of mid and final examinations, invigilating exams, evaluating student's work and assigning grades in compliance to the institute of higher education policy. Besides this, the basic responsibilities of teaching faculty toward student advising are concerning program requirements and related courses, and advising to students within department, incoming freshmen, transfer students and final year students. However, I usually doubt if each and every academic faculty follow the guideline and offer proper academic advising services to students. Moreover, my work experiences in the HEI show that an academic advisor is responsible to follow-up, guide, address student's issues, and facilitate academic matters of the same cohorts within the respective departments. Students are also responsible to contact and communicate with his/her advisor for advice and share ideas or issues that need solutions. In fact, students do not seem to take advantage of the advising services as needed. Accordingly, they face difficulties such as academic failure, pressure and peer influences. This could be due to student-advisor miscommunication, teachers' limited advising skills, and student's poor perception on academic advising.

Finally, the lack of research in students' advising from Eritrea and my personal interest in the field of higher education motivated me to examine the situation and understand the perspectives of students in HEIs. Using quantitative method many studies have been done on academic advising (Afshar \& Dhiman, 2008; Allard \& 
Students' perceptions on academic advising in higher education: A case of Eritrea Institute of Technology

Parashar, 2013; Muola, Maithya, \& Mwinzi, 2011; Shellenbarger \& Hoffman, 2016). However, little research has been conducted qualitatively to scrutinize students' views toward academic advising. Hence, using qualitative method, this study provides a comprehensive explanation from the students' real experiences that contributes to a better understanding of academic advising. Thus, the study contributes in filling the research gap and guiding the policy in ground regarding students' situation during their study time. It can also serve as a springboard for further study in similar context.

In conclusion, the current study intended to address the following research questions: i) how do undergraduate students' perceive academic advising at Eritrea Institute of Technology and ii) What are the challenges in academic advising as perceived by undergraduate students?

\section{The Concept of Academic Advising and Its Significance}

Academic advising is a common term, which defined as "the provision of academic-related information and guidance to students during their educational paths" (Trombley \& Holmes, 1981, p. 47). According to Owens (2015) academic advising is the process of advisor-advisee contact to solve academic related issues. A good relationship between advisee and advisor is important in the advising world. For instance, when a student faces some problems in his/her studies, they can contact easily their advisors to solve the existed problem when they have an effective connection between them. Whitmore (2016) also explains academic advising as the rational process in solving academic issues and facilitating effective decisions for the advantage of the student. Gordon, Habley and Grites (2008) defined academic advising as the process of providing information and directions to students concerning their academic, social or personal affairs. These definitions indicate that academic advising is a very imperative means of guiding and assisting students in solving various academic and social problems in the educational journey.

It is believed that academic advising began in American higher education during the 19th century for the purpose of assisting students in their educational goals (Johnson-Dedeaux, 2011). According to Gordon et al. (2008) and Peltier (2014), the faculty members carried out classroom instruction and student advising during the early eras. This means that all college activities including classroom instruction and non-academic activities like academic advising were the responsibility of the faculty. At the infant stage of academic advising, every student began to pair with the faculty member in order to get assistance in his/her educational and cognitive developments in American colleges and universities (Crookston, 2009; Johnson-Dedeaux, 2011). With the increased student diversity and more field of study, academic advising became crucial for assisting students. Then, Professional advisors trained to give advising services to students at advising centers in the 1970s (Johnson-Dedeaux, 2011). They deliver advising services like orientation and seminars in the centers to undecided students at post-secondary education. Advisors assist student while selecting courses, choosing major and exploring careers (O'Banion, 1994). Moreover, with the advancement of technology in universities, many students have begun to exchange information and communicate with their advisors through technology and register for their courses online (Al-Omari \& Khasawneh, 2014).

In addition, academic advising is believed as the main tool for students to continue persistently in their studies. It has been given great attention since the last four decades reflecting the belief in the importance of student development and retention (Crockett, 1978; Fielstein, 1989; Grites, 1981; Habley, 1982). Academic advising is becoming crucial to fostering student success in higher education. Crockett (1978) noted that frequent high-quality contact between advisee and advisor in college has a paramount significance in promoting students' learning. It is a fundamental tool to assist students in achieving educational, career and personal goals (Drake, 2011; Pargett, 2011). Through effective academic advising, students could fulfill their optimum potentials, to be competent enough in educational and personal life. Hence, in the educational paths, academic advising is the key aspect that promotes students learning in higher education (O'Banion, 1994). According to Pargett (2011) there is a positive correlation between academic advising with student success, student growth, and student satisfaction with college. Recently, higher education institutions (HEIs) of developing countries in Africa and 
Asia have been strengthening their undergraduate student services and programs in a way that promote students' learning, increases retention and graduation rates (Al-Omari \& Khasawneh, 2014; Chan, 2016; Megbo \& Abubakar, 2015). The study by Megbo and Abubakar (2015) stated that academic advising has the positive impact on students' performance. This implies that colleges or universities should provide quality services and a healthy learning environment for students in and outside the classroom.

On the other hand, Muola, Maithya, and Mwinzi (2011) noted that academic advising has no impact on the academic success of students. However, since advising is an effective strategy for students to develop positive academic experiences, greater responsibility, and strong study skills, it has a positive influence on students' success (Young-Jones, Burt, Dixon, \& Hawthorne, 2013). Having adequate information about institutional policies and personal capacities lead students to develop a roadmap for their educational goals and future aspirations (O’Banion, 1994). According to Metzner (1989) and Pargett (2011) when the relationships and interactions between advisee-advisor go well, students can develop better learning experiences and tend to complete their post-secondary education. On the other hand, due to advisors' lack of interpersonal skills, knowledge, and attitudes, and inaccessibility, learners cannot perceive academic advising as useful and important (Saba'Ayon, 2015). If students also do not use properly to academic advising due to lack of awareness, they face difficulties in solving problems and made unnecessary decisions in their educational paths (Drake, 2011). In this case, the researcher argues that students should be responsible for taking advantage of the academic advising services by contacting their advisors or vice-versa. Academic advisors assist students to accomplish their educational goals successfully by providing necessary information or direction on their educational and life plans. Academic advisors offer information about academic progress, degree requirements and review students' academic and educational needs, performances and challenges (O'Banion, 1994). Academic advising enables and empowers students to concentrate rigorously on their studies and grow academically and mentally in their life goals. For instance, according to UNESCO (1998) students can focus on their educational studies and complete successfully with the help of sound academic advising in universities or colleges.

Furthermore, academic advising helps students to become partners of higher education and acquaints them with their roles and responsibilities as learners (Drake, Jordan, \& Miller, 2013). Higher education institutions are responsible and take the initiative to develop the student in all dimensions, i.e. mentally, physically and socially (Ciobanu, 2013; Chickering \& Reisser, 1993; Ender, Winston, \& Miller, 1982). This can be achieved when the academic advisor and the whole community of the college become integrated and work to the advantage of the student. This collaboration among the university members enables and empower students to concentrate more on their studies which results in personal growth and academic success (Luescher-Mamashela, Moja, \& Schreiber, 2013). Academic advisors provide assistance, support for students to become confident, and guided with the campus experiences. To accomplish this mission, the academic advisor should have a comprehensive understanding about various options students they have in the college or university (O'Banion, 1994; Tinto, 1993; Pascarella \& Terezini, 1991). For instance, when a student wants to apply for a grade review, which does not belong to the advisor's work, an advisor should refer him/her to the concerned body. Moreover, if students receive the necessary educational guidance, they will score better results and complete their educational mission successfully (Shellenbarger \& Hoffman, 2016). The educational guidance received from their academic advisors can be prescriptive and developmental advising (Crookston, 1972). Prescriptive advising happens when an advisor offers information to students on what to do and the student listens passively with no input (Smith \& Allen, 2006). Educational assistance related to prescriptive advising practices may include explaining about prerequisite courses, registration, institutional policies, and procedures. Students need information when they would like to continue for further studies (Muola et al., 2011). For example, when students want to transfer from diploma to degree program or vice- versa, he/she should get enough information about what procedures need to follow. On the other hand, if students do not get effective advising services or do not interact with advisors, they could fail to meet the academic requirements that lead to withdrawal, dropout and dismissals from their studies (Tinto, 1993; Pascarella \& Terezini, 1991). In the developmental advising practice, an academic advisor offers academic information that gradually promotes further student's progress and development (Al-Omari \& 
Students' perceptions on academic advising in higher education: A case of Eritrea Institute of Technology

Khasawneh, 2014). When academic advisor provides the necessary information, students start to become self-confident to decide, think critically and show collaborative interaction with advisors.

\subsection{Models and Types of Academic Advising in Higher Education}

Various higher education institutions have different academic advising models. According to Gordon et al. (2008) advising deliver systems classified into three based on the organizational structure. These delivery models are decentralized, centralized and shared advising models in institutions (Gordon et al., 2008). In a decentralized model, advising is giving by the staff members in their academic departments. While in the centralized model, all advising services offered by the director and staff in one administrative unit. In the shared model, advising services takes place between the administrative unit and faculty in academic departments. Taking into consideration the idea of Gordon et al. (2008), from my personal experiences, the Eritrean HEIs use decentralized model in which the academic faculty gives advising at the departmental level to those who declared their majors. In the Eritrean context of the decentralized model, the ratio of academic advisor to advisee is approximately 1: 40. Moreover, to some extent, a centralized advising model is used to those who do not declare (freshman) their major. This takes place in one centralized office that carryout by academic faculty members who work at the freshman program office.

Higher education institutions have academic advising centers which carried out by professional advisors or faculty members (Cuseo, Fecas, \& Thompson, 2010). In American higher education, for example, academic advising performed by professional advisors rather than faculty teachers or student affairs personnel (National Academic Advising Association, 2006). While in England universities, the student personal tutor, a member of teaching faculty plays an academic advisor role to a small group of students. This practice may not be available in other parts of the world. In Kazakhstan colleges and universities, for example, having the professional advisor and personal tutor is not common like the UK and the US respectively. Nevertheless, 'the course coordinators and program managers are usually responsible for advising in Kazakhstan universities' (Abdykhalykova, 2013, p. 358). In some other countries, they make use of technology to assist academic advising efforts. This trend is reflected in Saudi Arabia, University of King Abdul Aziz that integrates advising into the university student information system (Noaman \& Ahmed, 2015).

According to Komives, Woodard, and Associates (2003) academic advising is a complex function that requires interpersonal skills, competencies, and knowledge. This means that in the manner of advisor and advisee interaction, an academic advisor should maintain a good culture of interpersonal communication skill and ability while interacting with the advisee. They also need to have a clear knowledge of individual differences so as students should feel satisfied by receiving good advising services. Moreover, students who have good attachment with the institution, feel secured environment to learn and having the clear purpose about their academic goals. This can lead students to persist in their educational endeavors (Teasley \& Buchanan, 2013). Pascarella and Terenzini (1991) note that students who receive quality feedback about their academic progress from their advisors show improvements. Berger and Braxton (1998) and Tinto (1987) also describes that strategies like the properly written booklet that contain college policies, orientation sessions and students' participation on college committees cultivate students' perceptions to persist in the college. This means that organizational or college characteristics and commitment could affect students' feelings and attitudes in using the advising services.

\subsection{Students' Perceptions towards Academic Advising}

In this section, the researcher analyzes various literatures to explore the current understanding of students' perceptions toward academic advising. Previous studies mainly examined student's satisfaction and awareness on academic advising (Saba'Ayon, 2015), student's preferences on faculty advisor and professional advisor (Allard \& Parashar, 2013), students' perceptions on the effectiveness of academic advisors (Owens, 2015), assessing student's satisfaction (Al-Ansari, Tantawi, Abdelsalam, \& Al-Harbi, 2015) and freshman perceptions 
on academic advising (Chan, 2016). The majority of studies agree that academic advising is significant to students' success if the faculty do their job properly.

Saba'Ayon (2015) noted that students were not satisfied with the academic advising services they receive at the Lebanon private university. The reason resulted in dissatisfaction with academic advising was advisors' lack of knowledge, skills, interest, and readiness. Accordingly, students perceived academic advising poorly or not helpful (Saba'Ayon, 2015). Allard and Parashar (2013) stated that there was high student interaction with faculty for advising purposes than with professional advisors in Northeastern United States University. Close interaction with professors/teachers at the departmental level helps students to get relevant information about their educational and personal goals. In his causal comparative findings, Owens (2015) noted that students did not view academic advisors do their jobs effectively in the university. On the other hand, this study indicated that academic advising function like providing relevant information and assisting students towards educational goals and success were perceived as important.

A quantitative study conducted by Al-Ansari et al. (2015) at the University of Dammam, Saudi Arabia indicated that academic advisors are easily accessible, cared and helpful to solve student's problems. This indicates that students were satisfied with the academic advising services due to the fact that their academic advisors are available and responsible for them. Furthermore, Chan (2016) conducted a qualitative study on freshman students and academic advisors perceptions on academic advising in Hong Kong. In his findings, Chan (2016) identified that freshman students perceived academic advising as relational, academic development, personal growth, and professional growth. This revealed that academic advising is helpful for freshman students in developing academic competence, choosing major and personal goals.

\subsection{Theoretical Foundation of the Study}

The foundational theory of this study is based on Astin's involvement theory. This theory is a highly used theory in many types of researches and tested in the field of higher education (Long, 2012) and it can help to address the current research questions.

Astin $(1984,1993)$ postulates five basic principles of involvement that can be applied to examine student's perceptions or experiences towards academic advising. The first principle describes the amount of physical and psychological energy a learner invests in various activities. For instance, when students get advise and are guided thoroughly on their educational paths, they may have higher experiences and then spend more energy on their studies. The second Astin's principle explains, regardless of its purpose, students' involvement is continuous in a way that students can contact their academic advisors based on consultation hour or any convenient time. Astin posits that, as a third point, effective involvement depends on the student's dedication to their academic work at the college. The fourth assumption refers that qualitative and quantitative student involvement in one program promotes students' learning and development. Finally, Astin's assumes that 'the effectiveness of any educational policy or practice is directly related to the capacity of that policy or practice to increase student's involvement' (Astin, 1984, p. 298). This implies that whenever there is intentional contact between advisor and advisee, clear supportive policies, institutional commitment and discussing academic progress to students can empower students to continue on their study. Pascarella and Terenzini (1991), and Long (2012) observe that the more students interact with the academic advisor, the high students become motivated and adapt with college experiences. The assumption is that when students get adequate help from their advisors, students perceive academic advising as useful and helpful for them in their studies. This could become meaningful when students interact with their academic advisors in which they help them to be familiar with the necessary college requirements and identify their interests, abilities, and motivation. Hence, Astin's involvement theory is relevant to this study for the reason it assumes that students should actively involve academically and socially in the college life.

Long (2012) states that students join to college with different backgrounds, abilities, past experiences, and 
Students' perceptions on academic advising in higher education: A case of Eritrea Institute of Technology

motivation that subsequently affect their academic successes. Long (2012) further argued that colleges and universities have their own unique academic standards, policies, procedures and social life. Freshman students, for instance are coming to college with less experience and looking for someone to guide them in making a decision about their program of study. In this instance, through sound academic advising, students can perceive themselves as cared and respected individuals when their advisors assist them in solving their difficulties and identifying their inclination fields in the college environment.

Moreover, Astin (1984) assumes that accessibility and readiness of faculty members and other staff are important to increase student's motivation to learn at the college. Academic faculty members who are responsible for advising should be available and ready to help their students. They should give enough time for advising and be flexible in assisting students. Institutions that build and create a supportive educational and social learning environment can enrich student's educational experiences (Kuh, Kinzie, Schuh, \& Whitt, 2011). To this effect, academic advisors should play an active role in guiding learners to integrate with the academic and social systems of higher education institutions. They should also examine the student's progress and guide them to other institutional resources (Tinto, 1993). Advisors can assist students during their transition from high school by making early contact, encouraging to put efforts in their academics and involving in extra-curricular activities, checking their academic progress and advising them for improvement (Owens, 2015). When advisors address this by providing clear and consistent information, students can learn actively and spend more time on their studies.

\section{Research Methodology}

The research is qualitative in nature with a case study design. Using a semi-structured interview, this study examined students' experiences or perceptions on academic advising. This method is helpful in finding in-depth data about students' feelings, attitudes, experiences and challenges on academic advising (Bogdan \& Biklen, 1992). It also enables the researcher to make the questions flexible and asking additional questions based on the response during an interviewee (Bryman, 2008). The sampling size of the study comprises twelve students who were registered in the academic year 2017/18 at Eritrea Institute of Technology (EIT). As this research focuses on the experiences of students on academic advising, the participants were selected purposively to incorporate the views of freshman and above students. This helped the researcher to find in-depth and relevant data from diverse participants with varied experiences about academic advising services. An interview protocol was prepared for students that describe the purpose of the study, instruction and the interview questions. The participation was voluntarily and took thirty to thirty-five minutes for each interviewee. During the interview, upon the permission of the participants, the researcher took notes and audio in order to help refer back and look at the interview data. Finally, after completing the interview, the researcher presented the transcription of the notes and the recorded audio to the participants for the authenticity of the data (Bryman, 2008).

EIT was selected by Purposive sampling due to its diversity of students that could represent a broader group of cases for the study (Teddlie \& Yu, 2007). The researcher also believes that with the diverse nature of the institute, students' problems are many and diverse that needs to scrutinize academic advising services in the lens of the undergraduate student's perspective. As it looks superficial to hide the identity of particular organizations in small country with few higher education institutions, the researcher did not prefer to keep the anonymity of the case higher education institute (Moosa, 2013). The researcher approached the participants through the proper channel with a letter from the vice president of the institute to the colleges. A thematic analysis was used to analyze the data. This method helps the researcher to organize and describe the data in detail in a way that gives meaningful interpretation and discussion (Braun \& Clarke, 2006; McNabb, 2008). The researcher used a pseudo name in presenting the data to keep confidential for the respondents' identity. These data then, coded and sorted into themes for further analysis and discussion. 


\section{Results and Discussions}

Academic advising is an essential service in facilitating students' educational and personal goals at higher education institutions. It is an interaction of the student with the advisor in search of information concerning academic matters (Gordon et al., 2008; Owens, 2015; Trombley \& Holmes, 1981). Students contact his/her advisor in seeking answers to their problems and the advisor replied immediately for their queries. The findings indicated that students get different prescriptive advising services such as guidance, taking grade results \& registration formalities, and receiving information. To some extent, the study revealed that students get some developmental advising including encouragement, relationship, and motivation.

\subsection{Guidance on Academic Rules and Regulations}

Academic rules and regulations are institutional rules that govern the overall academic activities of students in the college (NBHE, 2008). Students need to be familiar with academic rules and regulations. Advisors should guide their students in this matter. The participants viewed that their advisors provide guidance on institutional academic rules and regulations. Students have been giving written booklets when they join to the college. The majority of the interviewee mentioned that every student has been giving two booklets. The one booklet contains a description of academic rules and regulations of the institute. This booklet aims students to be familiar with the institutional policies and procedures.

The other booklet describes the student's code of conduct. It contains a description of students need to be disciplined and follow good ethical manners during their study. This helps students to develop ethical behaviors, which leads them to focus more on their studies and achieve their goals. In addition to this, the respondents said students receive a brief orientation about the institutional policies and procedures. This allows students to develop first-hand experiences with college environment that leads them to plan their educational journey from the early beginning. It also guides students concerning college policies, standards, and procedures. This finding support to Long (2012) in that students come to college with different background and experiences and the new environment (college) joined has also its own policies, standards, and procedures. Hence, giving a properly written handbook that contains college policies to students especially at first year is an effective strategy. This facilitates students understanding about the college and it empowers students to persist in their studies (Berger \& Braxton, 1998; Tinto, 1987). It also assists students to adjust into the new environment by making them familiar with the institutional policies and procedures (NBHE, 2010; Tinto, 1987).

\subsection{Frequency of Advisor-Advisee Contacts}

Regular contact between advisor and advisee is helpful to exchange updated information, following student's progress and addressing issues on time. Through frequent contacts, both parts can know each other, develop good rapport and solve problems on due time (Jordan, 2000). However, the current study revealed that advisee contacts to advisors for limited purposes like taking grade results and registration procedures. In this regard, the majority of the participants said that they contact their advisors for registration formalities at the beginning of the semester and collecting their semester grade report at the end of the semester. Advisors list all the required semester courses in the registration form and students go to their advisor's office to register and taking the signature of the advisor at the beginning of the semester. Similarly, at the end of the semester, students go to their advisor's office to collect their grade reports. This tells us that there is a limited interaction between the advisor and advisee at the institute. In this case, students did not show the culture of contacting their advisors frequently. For instance, students with good standing status may score "F" grade in one course and collect his/her result without having quality feedback, in which he/she may not have clear information when to clear the " $F$ " grade. Instead of contacting and discussing with his/her advisor at the right time on how to clear the "F" grade, they contact at last minute. If such things happen, students are forced to delay their graduation unnecessarily. The researcher believes that to alleviate such kind of cases, the contact should be from both sides. Not only the student should be responsible for his/her case, the advisor is also responsible to provide enough advice. 
Students' perceptions on academic advising in higher education: A case of Eritrea Institute of Technology

Therefore, frequent and high-quality contact between advisor and advisee is crucial for student success as stated by Crockett (1978).

\subsection{Advisors' Availability and offer information}

Advisors availability with clear consultation hours posted on their doors is an essential aspect in the process of academic advising. It facilitates students and advisors to interact and discuss ideas, opinions or solve problems in a good manner (Astin, 1984). This helps to take the necessary decisions about the raised issues, problems or in providing strong advising services (Crockett, 1978). The result of the study shows that advisors have an open door policy and offer information for their students. In line to this, most of the interviewee mentioned that advisors keep regular office hours and are easily accessible to them. However, few interviewees explained that though the regular registration or collecting grade report day and time is scheduled, sometimes they observe some advisors come very late and students wait long hours in front of the office. Then, the respondents claimed that they consume more time without doing anything and doubt when the advisor will come to the office. For instance, Kaleb said, "Sometimes, I come to collect my grade and see my academic progress. However, I couldn't find my advisor to help me understand my situation and plan ahead." This indicates that advisor's lack of accountability results rush meeting between advisor-advisee, which lead to limited advising session and dissatisfaction with the advising system. On the other hand, the majority of the respondents in the interview stated that advisors offer information for their students on course prerequisite, credit requirements, the deadline for add and drop courses, and re-admission procedures. In this instance, advisors are providing relevant information that can promote positive academic experiences for students at the college level. It also shows that advisors are responsible to guide, advise, share ideas and solve difficulties to their students. This finding validates the study of Cuseo et al. (2010), confirming that students have the experience in looking support and find immediate solutions to the raised issues.

\subsection{Advisor's Follow-Ups and Relationships}

Departments in higher education institutions assign academic advisors to their students in order to follow their academic progress and succeed in their educational goals. Advisors take care of their students from the early day of registration to graduation day (Cuseo et al., 2010). They communicate with each other by checking students' files and grades to identify the student's weaknesses and strengths (Plascarella \& Terenzini, 1991). Nevertheless, the result of the current study indicated that some students perceived that their advisors did not follow their academic progress by examining their files and grades. This indicates that students may not get information on time about their academic progress, as their advisors do not carefully follow their progress by checking their students' files and grades. However, this is not common to all advisors. In fact, there are advisors who considerably follow their advisee's academic progress by checking their files and grades. This kind of strategy is very effective in facilitating student growth by addressing different issues or alternatives in advance (Crookston, 2009; Jordan, 2000). The researcher argues that not all students need detailed guidance on their academic progress, as college level students have different experiences, academic abilities, and potentials. For instance, students with higher grades may need little academic guidance than students with lower grades. At the same time, fourth-year students are well experienced with the academic and administrative guidelines of the institution that needs little guidance. In addition, students with academic probation status should receive a proper advisement in advance from his/her advisor in order to persist on his/her studies. This could be done when the advisor knows his/her advisee academic situations by examining the student's grades and files.

Jordan (2000) states that good rapport between advisee and advisor is prominent as it facilitates in identifying advisee's interests and skills. In this regard, students easily explain their feelings, opinions and share their problems with their advisors in a meaningful way. When advisors support advisee for addressing the current issues or problems with diligence, clear, and consistent way, advisee can feel satisfied and secured (Jordan, 2000; Plascarella \& Terenzini, 1991; Tinto, 1991). This could motivate students to concentrate thoroughly on their study that leads to a better learning improvement. Building a close relationship between advisor and advisee is 
an important way in advising process. The researcher argues that both students and advisors should work cooperatively to make a strong working relationship. In fact, it is up to the advisor to follow the progress of their students in order to help them identify their strengths and potentialities. In relation to this, the study found that advisors encourage and motivate students to focus on their studies rigorously. Ali pointed out that his advisor encourages him in that he can able to improve his academic result. Ali said:

I remember last semester when I scored " $F$ " grade in one course. My advisor informed me to take a re-sit exam and he guides me very well on how to study and when to sit for the examination. Based on all the information and motivation he gave me, I studied hard with more fresh minded and my result improved as well.

Another interviewee, Simon said that last time he was in academic probation status in that it was out of his expectation. However, his advisor encourages him in that he could improve his academic status by taking a re-sit exam for one or two courses with lower grades. Then, he described that with the help of clear advisement of the advisor, he able to continue his study with the necessary improvements. In this regard, advisors play a great role in such kind of situation for encouraging students to focus more on their studies. Finally, Simon added that "we students do not play our role, we only contact our advisors when we face such kind of cases." The above two responses indicate that advisors guide students in preparation for the exam, motivate to be confident and achieve better outcomes.

\subsection{Challenges of Students on Academic Advising}

This section discusses the challenges of academic advising as perceived by students. The study found out that lack of advisors' accountability, lack of time management skills, as well as limited student's readiness and awareness are some of the challenges perceived by students on academic advising.

Accurate Information - Accurate information refers to relevant information about academic matters that foster student learning (Owens, 2015). In the study, few respondents answered that they have a challenge in getting accurate information from their advisors. This means that some advisors do not provide accurate information for their advisee when they contact them for directions. For example, two participants from freshman students said that they have a problem in finding accurate information about the available fields while choosing their major of study. They mentioned that they receive general information about each program overview through orientation before choosing their major that may not help for detailed information about the program they want to join. Hence, this shows freshman students are in need of strong advising services that facilitates for finding accurate information about their future field of study that matches with their interests.

Advisors' Openness and Readiness - Advisor's openness and readiness has a great impact in solving students' academic issues. In line to this statement, most of the respondents describe their advisors as approachable and friendly which encourages them to ask for any help freely. They also said that usually advisors are ready to help students, welcomed them, and they appreciate their advisors for what they do for them in every aspect of their academic journey. The participants state that in case of further need their advisors refer them to other concerned offices in compliance with the issue. For instance, Kokob explained that he had high expectation of scoring best result on the courses he attended, but unfortunately, he got one "B" and other lower grades that affected his motivation. Since he did not have any further clue about what to do for crosschecking his results, he contacted his advisor. Then, the advisor gave him helpful guidance and information on various alternative ways including information on the grading system of the department, the possibility for changing the grade, and finally, the advisor refers him to the registrar office for grade reviewing application. Regardless of the change in his grades, Kokob was happy with the treatment he got from his advisor. He felt that he was given the chance to be heard and motivation to upgrade him moral to do better in the coming semester.

On contrary, few respondents mentioned that some advisors are less cooperative to solve student's issues and hard to communicate with them. For example, Selam said that her advisor shows less interest on her and 
looks busy when she comes to contact him for any inquiry. Similarly, Aron explained that his advisor does not guide him with great zeal and seems as he is busy. In this case, the respondent added that he prefers to contact or share his cases with his colleagues or parents. In addition, an advisor should be responsible to follow his/her students with possible alternative ways. In some aspects, advisors were not committed to their responsibility. In line to this, Saba said that she was sick in the last academic year and handed an application letter and medical certificate to her advisor in support of her absence from taking a final exam. However, her advisor did not send the application letter to the respective department. Then, when she came back to school after treatment, the concerned body said to her that they didn't have any information about her case on due time. Later on, her advisor explained to the concerned body that the student had already submitted the application to the advisor but he (advisor) failed to forward to the concerned office. This indicated that some advisors did not follow-ups their students' cases on time. Such an incident brings administrative and other complication to the students.

Time Management and Study Skills - Time management skill is a fundamental tool in the educational journey at the college. Students face some challenges in managing their time in pursuing their studies. The research found that students have a great challenge in time management skills, especially during the examination. They described that they submit their exam papers to the invigilator without completing the required tasks. Subsequently, they scored lower grades in some courses, which lead them to frustration and anxiety. This reminds that advisors should help students on how to manage their time effectively in order to succeed in their educational endeavors. As far as the study skill is concerned, few respondents perceive that study skills as a challenge in the college. This means that there are some students who are in need of help in developing good study skills to achieve their educational goals.

Talking Freely - Talking freely with an advisor is an effective way in the process of academic advising. It can help students to express their ideas, feelings or issues to advisors in an understandable and consistent way. In line with this, most of the respondents said that they can talk freely about their cases with advisors and they can easily share their problems to advisors in their college experiences. For example, Senait said:

My advisor is very cooperative and friendly which encourages me to talk to him freely. Hence, when I have any idea or problem-related to my educational or personal goals, I discuss freely with my advisor. This is very helpful for my academics and personal development.

In contrast, other few participants do not talk freely with their advisors to solve problems in due time. This indicates that students unable to express their ideas in a clear picture about their problems to their respective advisors. In this case, these few respondents said that they prefer to share their problems with parents and colleagues due to shyness and some advisors' ineffectiveness.

\section{Conclusion}

Academic advising is the interaction between the advisor and students for sharing ideas, information and solving problems. According to Astin (1984), continuous contact between students and advisor is an effective way of promoting students learning at college. The study showed that there is a wide gap on the frequency of contact between advisor and advisee. The contact time is mainly done during registration time and at the end of the semester when students come to collect grade reports. This implies that generally there is a weak academic advising in Eritrean HEIs. Moreover, students contact their advisors for prescriptive advising purposes such as guidance, taking grade results, registration formalities, solving problems at difficult times and connect with other offices. This process of advising shows that students do not take advantage of advising services. E.g. Freshman students have limited understanding about academic advising. Then, it is significant for the higher education institution to consider the disadvantaged students mainly freshman students. In this regard, the study concluded that freshman students need greater support in identifying their inclination field while choosing majors. Students at the infant stage of their college life, it is difficult to make wise decisions about their future area and personal life (Drake, 2011). Hence, advisors need to be responsible to their advisee in solving such kind of problems 
through identifying students' potentials. Otherwise, it could have side effect on students' psychological wellbeing, eg. The student couldn't complete his/her study on time.

Furthermore, advisors should be responsible in giving the necessary and timely services for their students. It is also important that HEIs should have a minimum advising service per semester. In this regard, the study suggests besides contacts for registration formalities and collecting grades, at least student and advisor should meet two times in a semester. Astin's theory assumes that when students invest a greater amount of physical and psychological energy on their educational journey, they can achieve their educational goals. This can empower students to focus on their studies for better learning outcomes. In support of this assumption, the result indicated that proper advising promote students' academic improvement especially to students with lower academic performance. Indeed, when students get proper advising from advisors including educational guidance on study skills, time management procedures and proper academic progress follow-ups can motivate students to have a positive impact on their studies (Young-Jones et al, 2013). Through sound academic advising students can develop good academic proficiency and a stronger sense of readiness that lead to higher learning outcomes.

Students can face different challenges with regard to academic advising services. Students faced a challenge in finding accurate information in their educational paths due to advisor's lack of knowledge and skills regarding advising (Saba'Ayon, 2015). Other challenges for students regarding academic advising were lack of time management skill during the examination, lack of advisors' follow-ups, infrequent advisee-advisor contacts, shyness, and lack of close communication between advisee and advisor. This indicates that advisors did not guide their advisees properly that subsequently results in postponement of graduation. For example, when an advisor failed to provide the necessary information about the prerequisite course or other academic matters on due time, students do not finish their studies within the prescribed time. This poor academic advising might bring unnecessary implication in terms of financial and time to the students as well as the institution. In this regard, the researcher suggests that higher education institutions take into consideration the significance of academic advising through promoting advisor's experiences, knowledge, and skills on advising. In conclusion, students' experiences highlighted that academic advising need improvement.

This study is limited to presenting student's experiences or perceptions on academic advising process. Hence, further study is needed to examine the experiences of advisors and students' voices from other higher education institutions to understand the comprehensive process of academic advising in Eritrea.

\section{References}

Abdykhalykova, Z. (2013). Extended academic advising in Kazakhstan: Improving the success of first-year students. Procedia-Social and Behavioral Sciences, 89, 357-362. https://doi.org/10.1016/j.sbspro.2013.08.860

Afshar, T., \& Dhiman, S. (2008). Assessment of the excellence of academic advising: Lessons learned. Journal of College Teaching \& Learning, 5(3), 51-60.

Al-Ansari, A., El Tantawi, M., AbdelSalam, M., \& Al-Harbi, F. (2015). Academic advising and student support: Help-seeking behaviors among Saudi dental undergraduate students. The Saudi Dental Journal, 27(2), 57-62. https://doi.org/10.1016/j.sdentj.2014.11.011

Al-Omari, A. A., \& Khasawneh, S. A. (2014). Academic advising styles as perceived by undergraduate students in the Hashemite University, Jordan. Taibah University Journal of Educational Sciences, 9(1), 125-140. https://doi.org/10.12816/0015535

Allard, F. L., \& Parashar, S. (2013). Comparing undergraduate satisfaction with faculty and professional advisers: A multi-method approach. The Mentor: An Academic Advising Journal. Retrieved from http://dus.psu.edu/mentor/2013/08/comparing-satisfaction-faculty-professional-advisers

Astin, A. W. (1984). Student involvement: A developmental theory for higher education. Journal of College Student Personnel, 25(4), 297-308.

Astin, A. W. (1993). What matters in college: Four critical years revisited. San Francisco: 
Jossey-Bass.

Berger, J. B., \& Braxton, J. M. (1998). Revising Tinto's interactionalist theory of student departure through theory elaboration : Examining the role of organizational attributes in the persistence process. Research in Higher Education, 39(2), 103-119. https://doi.org/10.1023/A:1018760513769

Bogdan, R. G., \& Biklen, S. K. (1992). Qualitative research for education (2 $2^{\text {nd }}$ ed.). Boston, MA: Allyn \& Bacon.

Braun, V., \& Clarke, V. (2006). Using thematic analysis in psychology. Qualitative Research in Psychology, 3(2), 77-101. https://doi.org/10.1191/1478088706qp063oa

Bryman, A. (2008). Social research methods (3rd ed.), Oxford University Press, New York.

Chan, Z. C. Y. (2016). A qualitative study of freshmen's and academic advisors' perspectives on academic advising in nursing. Nurse Education in Practice, 18, 23-29. https://doi.org/10.1016/j.nepr.2016.02.010

Ciobanu, A. (2013). The role of student services in the improving of student experience in higher education. Procedia - Social and Behavioral Sciences, 92, 169-173. https://doi.org/10.1016/j.sbspro.2013.08.654

Chickering, A. W., \& L. Reisser, L. (1993). Education and identity (2nd ed.). San Francisco: Jossey-Bass.

Crockett, D. (1978). Academic advising : A cornerstone of student retention. New Directions for Student Services, 1978(3), 29-35. https://doi.org/10.1002/ss.37119780306

Crookston, R. B. (1972). A developmental view of academic advising as testing. Journal of College Student Personnel, 13(1), 12-17.

Crookston, B. B. (2009). A developmental view of academic advising as teaching. Journal of College Student Personnel, 29(1), 78-82. https://doi.org/10.12930/0271-9517-29.1.78

Cuseo, J., Fecas, V. S., \& Thompson, A. (2010). What all first-year students should know: The most potent, research-based principles of college success. Dubuque, IA: Kendall/Hunt.

Drake, J. K. (2011). The role of academic advising in student retention and persistence. About Campus, 16(3), 8-12. https://doi.org/10.1002/abc.20062

Drake, J. K., Jordan, P., \& Miller, M. A. (Eds.). (2013). Academic advising approaches: Strategies that teach students to make the most of college. San Francisco, CA: Jossey-Bass.

Ender, S. C., Winston, R. B., \& Miller, T. K. (1982). Academic advising as student development. New Directions for Student Services, 1982(17), 3-18. https://doi.org/10.1002/ss.37119821703

Fielstein, L. L. (1989). Student priorities do they want a personal relationship ? National Academic Advising Association Journal, 9(1), 33-38. https://doi.org/10.12930/0271-9517-9.1.33

Gordon, V. N., Habley, W. R., \& Grites, T. J. (Eds.). (2008). Academic advising: A comprehensive handbook. San Francisco, CA: Wiley.

Grites, T. J. (1981). Student and self-ratings of teacher-advisors. National Academic Advising Association Journal, 1(1), 29-33. https://doi.org/10.12930/0271-9517-1.1.29

Johnson-Dedeaux, V. M. (2011). An investigation of students' satisfaction with academic advising and students' impression of academic advisors at a rural community college (Doctorial dissertation), Mississippi State University, Mississippi, USA.

Jordan, P. (2000). Advising college students in the 21st century. National Academic Advising Association Journal, 20(2), 21-30. https://doi.org/10.12930/0271-9517-20.2.21

Habley, W. R. (1982). Academic advising: The critical link in student retention. NASPA Journal 18, 45-50.

Komives, S. R., Woodard, D. B., \& Associates. (2003). Student services: A handbook for the profession. San Francisco: Jossey-Bass.

Kuh, G. D., Kinzie, J., Schuh, J. H., \& Whitt, E. J. (2011). Student success in college: Creating conditions that matter. John Wiley \& Sons.

Long, D. (2012). Theories and models of student development. In L. J. Hinchliffe \& M. A. Wong (Eds.), Environments for student growth and development: Librarians and student affairs in collaboration (pp. 41-55). Chicago: Association of College \& Research Libraries.

Luescher-Mamashela, T., Moja, T., \& Schreiber, B. (2013). Towards a professionalisation of student affairs in Africa. Journal of Student Affairs in Africa, 1 (1\&2).

McNabb, D. E. (2008). Research methods in public administration and nonprofit management: Quantitative and qualitative approaches. New York: ME Sharpe. 
Frezghi, T.

Megbo, B. C., \& Abubakar, A. (2015). Is there an interconnection between academic advising and academic student performance? International Journal of Multidisciplinary Research \& Development, 2(9), $128-132$.

Metzner, B. (1989). Perceived quality of academic advising: The effect on freshman attrition. American Educational Research Journal, 26(3), 422-442. https://doi.org/10.3102/00028312026003422

Moosa, D. (2013). Challenges to anonymity and representation in educational qualitative research in a small community: A reflection on my research journey, Compare: A Journal of Comparative and International Education, 43(4), 483-495. https://doi.org/10.1080/03057925.2013.797733

Muola, J. M., Maithya, R., \& Mwinzi, A. M. (2011). The effect of academic advising on academic performance of university students in Kenyan universities. International Multidisciplinary Journal, 5(22), 332-345. https://doi.org/10.4314/afrrev.v5i5.26

National Academic Advising Association (NACADA) (2006). The global community for academic advising: National Academic Advising Association Concept of Academic Advising. Retrieved from http://www.nacada.ksu.edu/Resources/Clearinghouse/View-Articles/Concept-of-Academic-Advising-a5 98.aspx

National Board for Higher Education (2010). Governance and management of institutions of higher education, part $i$ - academics. Asmara, Eritrea.

National Board for Higher Education (2008). Rules and regulations pertaining to academic performances of students. Asmara, Eritrea.

National Board for Higher Education (2014). Higher education in Eritrea. Retrieved from http://www.cimo.fi/instancedata/prime_product_julkaisu/cimo/embeds/cimowwwstructure/55342_4319 2_HE_IN_ERITREA_Tadesse_Mehari.pdf

Noaman, A. Y., \& Ahmed, F. F. (2015). A New framework for e academic advising. Procedia Computer Science, 65, 358-367. https://doi.org/10.1016/j.procs.2015.09.097

O'Banion, T. (1994). An academic advising model. National Academic Advising Association Journal, 14(2), 10-16. https://doi.org/10.12930/0271-9517-14.2.10

Owens, M. R. (2015). Student perceptions of academic advisor effectiveness and student success : Factors that matter (Doctoral dissertation), Eastern Illinois university.

Pargett, K. K. (2011). The effects of academic advising on college student development in higher education (Masteral thesis), University of Nebraska.

Pascarella, E. T., \& Terenzini, P. T. (1991). How college affects students: Findings and insights from twenty years of research. San Francisco: Jossey-Bass.

Peltier, M. S. (2014). The impact of faculty perception of student affairs personnel on collaborative initiatives : A case study (Doctoral Dissertation), University of Nebraska - Lincoln.

Rena, R. (2006): Gender disparity in education: An Eritrean perspective, The Global Child Journal, 2(1), 43-49.

Saba'Ayon, N. (2015). Academic advising: Perceptions of students in a Lebanese university. IJAEDU-International E-Journal of Advances in Education, 1(2), 118-126. https://doi.org/10.18768/ijaedu.26010

Shellenbarger, T., \& Hoffman, R. (2016). Advising 101: Lessons in advising for nursing student success. Teaching and Learning in Nursing, 11(3), 92-100. https://doi.org/10.1016/j.teln.2016.01.006

Smith, C. L., \& Allen, J. M. (2006). Essential functions of academic advising: What students want and get. National Academic Advising Association Journal, 26(1), 56-66. https://doi.org/10.12930/0271-9517-26.1.56

Teasley, M. L., \& Buchanan, E. M. (2013). Capturing the student perspective: A new instrument for measuring advising satisfaction. National Academic Advising Association Journal, 33(2), 4-15. https://doi.org/10.12930/NACADA-12-132

Teddlie, C., \& Yu, F. (2007). Mixed methods sampling: A typology with examples. Journal of Mixed Methods Research, 1(1), 77-100. https://doi.org/10.1177/2345678906292430

Tinto, V. (1987). Increasing student retention. San Francisco: Jossey Bass. 
Students' perceptions on academic advising in higher education: A case of Eritrea Institute of Technology

Tinto, V. (1993). Leaving college: Rethinking the causes and cures of student attrition ( $2^{\text {nd }}$ ed.). University of Chicago Press.

Trombley, T. B., \& Holmes, D. (1981). Defining the role of academic advising in the industrial setting: The next phase a profession of futurists. National Academic Advising Association Journal, 29(1), 47-51.

United Nations Educational, Scientific and Cultural Organization (UNESCO). (1998, October 5-9). Higher education in the twenty-first century: Vision and action. Paper presented at World Conference on higher education, UNESCO, Paris, France.

Whitmore, W. T. (2016). Student perceptions of academic advising at two- year colleges (Doctoral dissertation), Minnesota State University, Minnesota.

Young-Jones,A.D., Burt, T.D., Dixon,S. \& Hawthorne, M.J.(2013). Academic advising: Does it really impact student success? Quality Assurance in Education, 21(1), 7-19.

https://doi.org/10.1108/09684881311293034 
Frezghi, T. 